\title{
Sex differences in fetal activity and childhood hyperactivity
}

\author{
Lee Ellis* and Ping $\mathrm{He}$ \\ *Correspondence: lee.ellis@hotmail.com

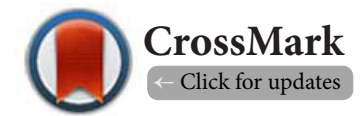

Independent Researchers, USA.

\begin{abstract}
Background: Most studies have failed to identify significant sex differences in movement (or activity) during fetal development. However, the sample sizes and lengths of time fetuses were monitored in these studies have been limited.

Aim and methods: Using the recollections provided by a sample of 6,546 mothers, this study examines variations in fetal activity levels for every month of pregnancy. Evidence was also sought that fetal activity might beassociated with hyperactivity/ hyperkinesis following birth.

$\underline{\text { Results: }}$ By the fourth month of pregnancy, mothers reported that males were significantly more active in the womb than females. Also, fetal activity was positively correlated with hyperactivity following birth, especially for males.

Conclusion: Despite numerous prior studies derived from small samples failing to reveal significant sex differences in fetal activity, the present study demonstrates that males are about $10 \%$ more active than females during the latter two-thirds of pregnancy and are even more so following birth. Furthermore, even within each gender, fetal activity predicted hyperactivity in childhood, thus indicating that there must be a common biological root for variations in activity levels.
\end{abstract}

Keywords: Fetal activity/movement, childhood hyperactivity/hyperkinesis, sex differences, pregnancy

\section{Introduction}

Nearly all research has concluded that boys are more physically active than girls [1,2]. Furthermore, male children are more likely than female children to be diagnosed hyperactive or ADHD [3].

What causes greater activity among males continue to be debated. Many social and behavioral scientists favor sociocultural learning explanations [4-7] while others have proposed that biological factors are of paramount importance [1,8-11]. Relevant to the debate is the possibility that males are more active even in utero. This is because sex differences prior to birth would preclude the possibility that social learning is responsible for the differences.

Several studies have reported on sex differences in fetal activity. While two of these studies reported that male fetuses were more active than female fetuses $[12,13]$, the majority have indicated that the differences are non-significant [14-17]. It is important to note that all of these studies were based on samples of less than one hundred pregnant women and that the time during which each woman was monitored with ultra sound were typically less than two hours. The limited sample sizes and time frames covered by these studies could obviously explain why most studies have reported no significant gender difference when in fact at least a small difference exists.

The present study was undertaken to help settle the issue of sex differences in fetal movement by examining evidence from a large sample. We were also interested in determining if fetal movement might predict hyperactivity in childhood. In both cases, we assumed the null hypothesis.

\section{Methods \\ Sample}

Over 11,000 students at twenty United States universities and two Canadian universities were asked to invite their mothers to complete a questionnaire about their pregnancy history with the students. Students who were adopted or whose mothers were no longer living were exempted from the request. This resulted in 6,546 mothers volunteering to complete a lengthy (ten-page) questionnaire.

The average age of the mothers completing a questionnaire was 47.98 ( $S D=7.61)$, and their average years of education was 13.7 years $(S D=2.45)$. Ethnically, $95.2 \%$ of the mothers were non-Hispanic white, $1.2 \%$ were black, $1.3 \%$ were Hispanic, $1.3 \%$ were Native American, while 1.0\% were not disclosed.

\section{Variable measurement}

To measure fetal movement (herein called fetal activity), mothers were asked to report the extent to which the offspring that was the "focus of this study" (i.e., the college student through which contact with the mother was made) was active during each month of pregnancy. Mothers provided responses on a month-by-month basis using a ten-point rating scale, with 0 meaning not at all to 9 meaning to an extreme degree. Elsewhere on the questionnaire, mothers were asked to rate the offspring in terms of exhibiting symptoms of hyperactivity/hyperkinesis, 
Ellis et al. Research Journal of Developmental Biology 2014,

http://www.hoajonline.com/journals/pdf/2055-4796-1-1.pdf

doi: $10.7243 / 2055-4796-1-1$

again using a ten-point scale ranging from 0 to 9 .

\section{The validity of the mother's fetal activity estimates}

The validity of mother's reports of fetal activity is rather central to the present study. Because fetal movement has been used for decades to gage healthy fetal development and maternal assessments in this regard are often used, considerable research has compared maternal assessments with more objective measures, such as ultrasound readings [18]. Even though ultrasound movement detection has been shown to be much more sensitive to minor movements than maternal reports, they have been shown to correlate highly. One frequently cited study obtained a $0.739(p<0.001)$ between the two [19]. According to a literature review, research based on ultrasound and other objective measures "have concluded that mothers reliably record fetal activity" [20]. Another author suggested "that maternal perception of major fetal body movements is accurate in the majority of cases" [21,22-24].

The other issue surrounding the validity of the data to be presented has to do with how well mothers recall pregnancyrelated events such as fetal movement twenty-odd years after the fact. We are aware of no research specifically pertaining to fetal movement in this regard. However, studies comparing medical records obtained during pregnancy with mothers' recall years later have been reported. For a variety of traits, maternal recall has proven to be quite accurate $[25,26]$. For example, one study compared data collected during pregnancy with the mothers' recollections of having smoked while pregnant $30+$ years later. The correlation coefficient between these two measures was 0.86 [27]. A similarly designed study concluded that mothers exhibit "high stability and consistency in retrospective recall of smoking" while pregnancy [28].

Other studies have compared officially recorded birth weight and gestational age with mothers' recollections several years later. One study concluded that while accuracy declined somewhat as years passed, "maternal recall of birthweight and gestational age of previous children is sufficiently accurate for clinical and even for epidemiological use" [29,30].

Overall, it would be preferable to collect ultrasound data throughout pregnancy to determine fetal movement rather than utilizing maternal recall some twenty years after the fact. However, since no such data are known to exist for a large sample of mothers, the present retrospective data are herein reported.

Comparisons between males and females were made using t-tests for independent samples. To determine whether or not fetal activity and childhood hyperactivity were related, Pearson correlation was employed.

\section{Results}

Sex differences in monthly reports of fetal movement along with sex differences in childhood hyperactivity/hyperkinesis are summarized in Table 1. As one can see, in the first three months, no significant sex differences were reported by mothers in fetal activity. Also worth noting is that average fetal activity levels even in the latter trimester were rated fairly low by the mothers, i.e., always less than 3 on a 9-point rating scale.

Table 1. Gender differences in fetal activity throughout pregnancy and hyperactivity/hyperkinesis as a child.

\begin{tabular}{l|lllll}
\hline \multirow{2}{*}{$\begin{array}{l}\text { Activities \& Months } \\
\text { of Pregnancy }\end{array}$} & \multicolumn{2}{l|}{ Gender (Mean \& SEM) } & \multirow{2}{*}{ t-score } & Significance \\
\cline { 2 - 3 } & Male & Female & & \\
\hline $1^{\text {st }}$ month & $0.10(0.016)$ & $0.07(0.010)$ & 1.433 & 0.152 \\
$2^{\text {nd }}$ month & $0.13(0.018)$ & $0.10(0.010)$ & 1.516 & 0.130 \\
$3^{\text {rd }}$ month & $0.40(0.026)$ & $0.35(0.017)$ & 1.589 & 0.112 \\
$4^{\text {th }}$ month & $1.09(0.042)$ & $0.97(0.028)$ & 2.412 & 0.016 \\
$5^{\text {th }}$ month & $1.71(0.054)$ & $1.59(0.037)$ & 1.952 & 0.051 \\
$6^{\text {th }}$ month & $2.22(0.065)$ & $2.08(0.044)$ & 1.846 & 0.065 \\
$7^{\text {th }}$ month & $2.66(0.074)$ & $2.45(0.049)$ & 2.289 & 0.022 \\
$8^{\text {th }}$ month & $2.91(0.080)$ & $2.66(0.053)$ & 2.568 & 0.010 \\
$9^{\text {th }}$ month & $2.84(0.081)$ & $2.56(0.053)$ & 2.877 & 0.004 \\
Postnatal hyperactivity & $0.17(0.015)$ & $0.07(0.007)$ & 5.672 & 0.000
\end{tabular}

Table 1 shows that significant sex differences began to appear on the fourth month, with males being more active than females. These difference persist in being statistically significant throughout the remainder of pregnancy except for the sixth month when the difference was just shy of significance. Therefore, we are obliged to reject the null hypothesis and accept that males exhibit greater fetal activity, at least during the second and third trimesters. To determine if childhood hyperactivity is correlated with fetal activity, maternal estimates of both were correlated for males and females separately. The results appear in Table 2. There one can see that childhood hyperactivity for males was positively correlated with hyperactivity for every month of pregnancy. In the case of females, significant correlations were also found, except for the first three months and the ninth month of pregnancy. Consequently, we must again reject the null hypothesis and conclude that childhood hyperactivity is associated with tendencies to be unusually active during fetal development, especially for males.

\section{Discussion}

The present study has indicated that by the second trimester, male fetuses begin to surpass female fetuses in activity levels and that they continue doing so throughout the remainder of pregnancy. This finding is consistent with two prior studies $[12,13]$ but contrary to most indicating no significant sex differences in fetal activity [2,14-17]. Given that all of these studies were based on samples of less than one hundred while the present study was derived from a sample of more than six and a half thousand, the inconsistency may be attributed to the much greater statistical power in the present study. Nevertheless, the long delay in maternal recollections in the 
Table 2. Correlations between activity levels during each month of pregnancy and childhood hyperactivity/hyperkinesis for males and females separately.

\begin{tabular}{|c|c|c|}
\hline Month of Pregnancy & Gender & $\begin{array}{l}\text { Childhood } \\
\text { Hyperactivity/Hyperkinesis }\end{array}$ \\
\hline $1^{\text {st }}$ month & $\begin{array}{l}\text { Male } \\
\text { Female }\end{array}$ & $\begin{array}{l}0.080^{* * * *} \\
-0.015\end{array}$ \\
\hline $2^{\text {nd }}$ month & $\begin{array}{l}\text { Male } \\
\text { Female }\end{array}$ & $\begin{array}{l}0.092^{* * * *} \\
0.005\end{array}$ \\
\hline $3^{\text {rd }}$ month & $\begin{array}{l}\text { Male } \\
\text { Female }\end{array}$ & $\begin{array}{l}0.140^{* * * *} \\
0.017\end{array}$ \\
\hline $4^{\text {th }}$ month & $\begin{array}{l}\text { Male } \\
\text { Female }\end{array}$ & $\begin{array}{l}0.112^{* * * *} \\
0.039^{* *}\end{array}$ \\
\hline $5^{\text {th }}$ month & $\begin{array}{l}\text { Male } \\
\text { Female }\end{array}$ & $\begin{array}{l}0.099^{* * * *} \\
0.044^{* * *}\end{array}$ \\
\hline $6^{\text {th }}$ month & $\begin{array}{l}\text { Male } \\
\text { Female }\end{array}$ & $\begin{array}{l}0.086^{\star * * *} \\
0.046^{\star * *}\end{array}$ \\
\hline $7^{\text {th }}$ month & $\begin{array}{l}\text { Male } \\
\text { Female }\end{array}$ & $\begin{array}{l}0.085^{* * *} \\
0.039^{* *}\end{array}$ \\
\hline $8^{\text {th }}$ month & $\begin{array}{l}\text { Male } \\
\text { Female }\end{array}$ & $\begin{array}{l}0.072^{* * *} \\
0.037^{*}\end{array}$ \\
\hline $9^{\text {th }}$ month & $\begin{array}{l}\text { Male } \\
\text { Female }\end{array}$ & $\begin{array}{l}0.064^{* * *} \\
0.023\end{array}$ \\
\hline
\end{tabular}

present study may also be a factor.

Furthermore, boys greatly surpassed girls in terms of childhood hyperactivity (Table 1), a conclusion also reached by nearly all previous research [3]. Perhaps the more important finding from the present study was that prenatal activity levels correlated with hyperactivity during childhood, especially for boys.

Results from this study call strict social learning explanations of sex differences in activity levels into question and suggest instead that biology plays a role in determining these differences. Prominent among biological explanations offered in recent years are those hypothesizing that prenatal testosterone and other androgens has life-long effects on many aspects of human behavior, including overall activity levels $[9,11,31,32]$. According to this perspective, when the brain is prenatally exposed to high levels of androgens (and their metabolites) its functioning is permanently altered in ways that promote a wide range of motor activities [33-35]. Besides offering an explanation for sex differences in activity levels, this view conforms with evidence that young girls with congenital adrenal hyperplasia $(\mathrm{CAH})$, a condition associated with an excess production of androgens, are unusually active compared to age-matched girls without $\mathrm{CAH}[9,11,33,36]$.

Limitations of the present study include the fact that we relied on retrospective accounts by mothers whose memories have faded after twenty-odd years, especially for mothers who had given birth to several offspring. Nevertheless, verification studies have indicated that mothers' recollections of their pregnancy experiences tend to be highly reliable even decades later [27,37].

Another possibility is that a mother's recall of fetal activity could have actually been biased by knowledge of the offspring's sex. In other words, simply knowing that their child was a boy rather than a girl, and that boys are supposed to be more active, could have caused the mothers to bias their estimates of fetal movement upward for boys. Such a possibility deserves scrutiny by future studies. However, we are inclined to doubt such an occurrence for two reasons: First, one can see from Table 1 that the estimates of fetal movement were specific to the last two trimesters of pregnancy. If women were providing biased estimates, there is little reason to believe that they would have been limited to this time frame. Second, even if such a bias occurred, one is still left with the finding that within each sex of offspring, fetal activity was associated with childhood hyperactivity.

As a final limitation, nearly all of the participants in this study were English speaking citizens of North America. Therefore, comparable studies in other parts of the world should be undertaken.

We believe that the most likely explanation of this study's findings regarding both sex differences in physical activity before and after birth as well as within-sex associations between prenatal and postpubertal activity levels have biological underpinnings. Specifically, fetal brain exposure to androgens appears to promote physical activity both in humans $[32,38,39]$ and in rats $[40]$. By the second trimester of gestation, male gonads have formed into functioning testes, thereby producing testosterone at higher levels than female ovaries $[\mathbf{4 1 , 4 2}]$. This prenatal exposure to testosterone permanently organizes the brain in ways that promote greater physical activity throughout life $[43,44]$. As a consequence, males tend to be more active than females before birth as well as afterward. Furthermore, due to considerable withinsex variations in brain exposure to testosterone while the brain is being sexed perinatally, activity levels before birth positively correlates with activity levels following birth even within each sex.

No scientific study settles controversies once and for all. Nonetheless, if the present findings can be confirmed, they suggest that biological factors are making a significant contribution to sex differences in activity levels.

\section{Competing interests}

The authors declare that they have no competing interests.

\section{Authors' contributions}

\begin{tabular}{|l|c|c|}
\hline Authors' contributions & LE & PH \\
\hline Research concept and design & $\checkmark$ & -- \\
\hline Collection and/or assembly of data & $\checkmark$ & $\checkmark$ \\
\hline Data analysis and interpretation & $\checkmark$ & -- \\
\hline Writing the article & $\checkmark$ & -- \\
\hline Critical revision of the article & $\checkmark$ & -- \\
\hline Final approval of article & $\checkmark$ & -- \\
\hline Statistical analysis & $\checkmark$ & $\checkmark$ \\
\hline
\end{tabular}


Ellis et al. Research Journal of Developmental Biology 2014,

http://www.hoajonline.com/journals/pdf/2055-4796-1-1.pdf

doi: $10.7243 / 2055-4796-1-1$

\section{Acknowledgement}

We thank the mothers who were so kind as to complete a questionnare for this study.

Publication history

Senior Editor: Tzi Bun Ng, The Chinese University of Hong Kong, China. Received: 11-Jan-2014 Final Revised: 26-Feb-2014

Accepted: 08-Mar-2014 Published: 02-Apr-2014

\section{References}

1. Campbell D. W and Eaton W. O. Sex differences in the activity level of infants. Infant and Child Development. 1999; 8:1-17. | Article

2. Eaton $W O$ and Enns LR. Sex differences in human motor activity level. Psychol Bull. 1986; 100:19-28. | Article | PubMed

3. Ellis $L$, Hershberger $S$, Field $E$, Wersinger $S$, Pellis $S$, Geary D, Palmer $C$, Hoyenga K, Hetsroni A and Karadi K. Sex differences: Summarizing more than a century of scientific research. New York: Psychology Press. 2008. | Article

4. Eagly A. H, Wood W and Diekman A. B. Social role theory of sex differences and similarities: A current appraisal. In T. Eckes\& $H$. M. Trautner (Eds.), The developmental social psychology of gender. Mahwah, NJ: Lawrence Erlbaum Associates. 2000; 123-174.

5. Fagot B. I and O'Brien M. Activity level in young children: Cross-age stability, situational influences, correlates with temperament, and the perception of problem behaviors. Merrill-Palmer Quarterly. 1994; 40:378-398.

6. Prior $M$, Smart $D$, Sanson $A$ and Oberklaid F. Sex differences in psychological adjustment from infancy to 8 years. J Am Acad Child Adolesc Psychiatry. 1993; 32:291-304. | Article | PubMed

7. Wood W and Eagly AH. A cross-cultural analysis of the behavior of women and men: implications for the origins of sex differences. Psychol Bull. 2002; 128:699-727. | Article | PubMed

8. Berenbaum SA. Effects of early androgens on sex-typed activities and interests in adolescents with congenital adrenal hyperplasia. Horm Behav. 1999; 35:102-10. | Article | PubMed

9. Berenbaum S. A and Hines M. Early androgens are related to childhood sex-typed toy preferences. Psychological Science. 1992; 3:203-206. | Article

10. Sagvolden T, Johansen EB, Aase $H$ and Russell VA. A dynamic developmental theory of attention-deficit/hyperactivity disorder (ADHD) predominantly hyperactive/impulsive and combined subtypes. Behav Brain Sci. 2005; 28:397-419. | Article | PubMed

11. Servin A, Nordenstrom A, Larsson A and Bohlin G. Prenatal androgens and gender-typed behavior: a study of girls with mild and severe forms of congenital adrenal hyperplasia. Dev Psychol. 2003; 39:440-50. | Article | PubMed

12. Almli CR, Ball RH and Wheeler ME. Human fetal and neonatal movement patterns: Gender differences and fetal-to-neonatal continuity. Dev Psychobiol. 2001; 38:252-73. | Article | PubMed

13. DiPietro JA, Hodgson DM, Costigan KA, Hilton SC and Johnson TR. Fetal neurobehavioral development. Child Dev. 1996; 67:2553-67. | Article | PubMed

14. DiPietro JA, Costigan KA, Shupe AK, Pressman EK and Johnson TR. Fetal neurobehavioral development: associations with socioeconomic class and fetal sex. Dev Psychobiol. 1998; 33:79-91. | Article | PubMed

15. DiPietro JA, Kivlighan KT, Costigan KA and Laudenslager ML. Fetal motor activity and maternal cortisol. Dev Psychobiol. 2009; 51:505-12. | Article | PubMed Abstract | PubMed Full Text

16. Groome LJ, Swiber MJ, Holland SB, Bentz LS, Atterbury JL and Trimm RF, $3 \mathrm{rd}$. Spontaneous motor activity in the perinatal infant before and after birth: stability in individual differences. Dev Psychobiol. 1999; 35:15-24. | Article | PubMed

17. Pillai $M$ and James D. Are the behavioural states of the newborn comparable to those of the fetus? Early Hum Dev. 1990; 22:39-49. I Article | PubMed

18. Swanson RW. Daily maternal counting of fetal movement as an antenatal screening test. Part I. A review. Can Fam Physician. 1988; 34:561-5. | PubMed Abstract | PubMed Full Text

19. Gettinger $A$, Roberts $A B$ and Campbell $S$. Comparison between subjective and ultrasound assessments of fetal movement. $\mathrm{Br}$ Med J. 1978; 2:88-90. | Article | PubMed Abstract | PubMed Full Text

20. Hertogs K, Roberts AB, Cooper D, Griffin DR and Campbell S. Maternal perception of fetal motor activity. Br Med J. 1979; 2:1183-5. | Article | PubMed Abstract I PubMed Full Text

21. Schmidt W, Cseh I, Hara K and Kubli F. Maternal perception of fetal movements and real-time ultrasound findings. J Perinat Med. 1984; 12:313-8. | Article | PubMed

22. Kisilevsky BS, Killen H, Muir DW and Low JA. Maternal and ultrasound measurements of elicited fetal movements: a methodologic consideration. Obstet Gynecol. 1991; 77:889-92. | PubMed

23. Trudinger BJ and Cook CM. Fetal breathing movements--a comparison of hard copy records produced by M-mode and Doppler ultrasound. Early Hum Dev. 1989; 20:247-53. I Article | PubMed

24. Hijazi ZR, Callan SE and East CE. Maternal perception of foetal movement compared with movement detected by real-time ultrasound: an exploratory study. Aust N Z J Obstet Gynaecol. 2010; 50:144-7. | Article | PubMed

25. Buka SL, Goldstein JM, Spartos E and Tsuang MT. The retrospective measurement of prenatal and perinatal events: accuracy of maternal recall. Schizophr Res. 2004; 71:417-26. | Article | PubMed

26. Yawn BP, Suman VJ and Jacobsen SJ. Maternal recall of distant pregnancy events. J Clin Epidemiol. 1998; 51:399-405. | Article I PubMed

27. Tomeo CA, Rich-Edwards JW, Michels KB, Berkey CS, Hunter DJ, Frazier AL, Willett WC and Buka SL. Reproducibility and validity of maternal recall of pregnancy-related events. Epidemiology. 1999; 10:774-7. | Article | PubMed

28. Post A, Gilljam H, Bremberg S and Galanti MR. Maternal smoking during pregnancy: a comparison between concurrent and retrospective selfreports. Paediatr Perinat Epidemiol. 2008; 22:155-61. | Article | PubMed

29. Seidman DS, Slater PE, Ever-Hadani P and Gale R. Accuracy of mothers' recall of birthweight and gestational age. Br J Obstet Gynaecol. 1987; 94:731-5. | Article | PubMed

30. Tilley BC, Barnes AB, Bergstralh E, Labarthe D, Noller KL, Colton T and Adam E. A comparison of pregnancy history recall and medical records. Implications for retrospective studies. Am J Epidemiol. 1985; 121:26981. | Article | PubMed

31. Ellis L. Identifying and explaining apparent universal sex differences in cognition and behavior. Personality and Individual Differences. 2011; 51:552-561. | Article

32. Pasterski V, Hindmarsh P, Geffner M, Brook C, Brain C and Hines M. Increased aggression and activity level in 3- to 11-year-old girls with congenital adrenal hyperplasia (CAH). Horm Behav. 2007; 52:368-74. | Article | PubMed Abstract | PubMed Full Text

33. Alexander GM and Peterson BS. Testing the prenatal hormone hypothesis of tic-related disorders: gender identity and gender role behavior. Dev Psychopathol. 2004; 16:407-20. | Article | PubMed

34. Martel MM, Klump K, Nigg JT, Breedlove SM and Sisk CL. Potential hormonal mechanisms of attention-deficit/hyperactivity disorder and major depressive disorder: a new perspective. Horm Behav. 2009; 55:465-79. | Article | PubMed Abstract | PubMed Full Text

35. Sullivan SD and Moenter SM. Prenatal androgens alter GABAergic drive to gonadotropin-releasing hormone neurons: implications for a common fertility disorder. Proc Natl Acad Sci U S A. 2004; 101:7129-34. | Article | PubMed Abstract | PubMed Full Text

36. Meyer-Bahlburg HF, Dolezal C, Baker SW, Carlson AD, Obeid JS and New MI. Prenatal androgenization affects gender-related behavior but not gender identity in 5-12-year-old girls with congenital adrenal hyperplasia. Arch Sex Behav. 2004; 33:97-104. | Article | PubMed 
Ellis et al. Research Journal of Developmental Biology 2014,

37. Fingerhut L. A, Kleinman J. C and Kendrick J. S. Smoking before, during, and after pregnancy. American Journal of Public Health. 1990; 80:541544. | Article

38. Grimshaw GM, Sitarenios $G$ and Finegan JA. Mental rotation at 7 years: relations with prenatal testosterone levels and spatial play experiences. Brain Cogn. 1995; 29:85-100. | Article | PubMed

39. Hönekopp J, Rudolph U, Beier L, Liebert A and Müller C. Physical attractiveness of face and body as indicators of physical fitness in men. Evolution and Human Behavior. 2007; 28:106-111. I Pdf

40. Hotchkiss AK, Ostby JS, Vandenburgh JG and Gray LE, Jr. Androgens and environmental antiandrogens affect reproductive development and play behavior in the Sprague-Dawley rat. Environ Health Perspect. 2002; 110 Suppl 3:435-9. | Article | PubMed Abstract | PubMed Full Text

41. Bendsen E, Byskov AG, Laursen SB, Larsen HP, Andersen CY and Westergaard LG. Number of germ cells and somatic cells in human fetal testes during the first weeks after sex differentiation. Hum Reprod. 2003; 18:13-8. | Article | PubMed

42. Voutilainen R. Differentiation of the fetal gonad. Horm Res. 1992; 38 Suppl 2:66-71. | Article | PubMed

43. Hines M. Prenatal endocrine influences on sexual orientation and on sexually differentiated childhood behavior. Front Neuroendocrinol. 2011; 32:170-82. | Article | PubMed Abstract | PubMed Full Text

44. Mosley JL and Stan EA. Human sexual dimorphism: its cost and benefit. Adv Child Dev Behav. 1984; 18:147-85. | PubMed

\section{Citation:}

Ellis $\mathrm{L}$ and $\mathrm{He}$ P. Sex differences in fetal activity and childhood hyperactivity. Res J Dev Biol. 2014; 1:1. http://dx.doi.org/10.7243/2055-4796-1-1 